\title{
Novel Gas Sensors for High-Temperature Fossil Fuel Applications
}

\author{
Semi-annual Report
}

\author{
Reporting Period: 1 May 2004 to 31 October 2004 \\ Prepared by: \\ Dr. Palitha Jayaweera \\ May 2004 \\ Prepared for: \\ Department of Energy \\ Award Number: DE-FC26-03NT41921
}

\begin{abstract}
Submitted by:
SRI International

333 Ravenswood Ave.

Menlo Park, CA 94025
\end{abstract}




\section{DISCLAIMER}

This report was prepared as an account of work sponsored by an agency of the United States Government. Neither the United States Government nor any agency thereof, nor any of their employees, makes any warranty, express or implied, or assumes any legal liability or responsibility for the accuracy, completeness, or usefulness of any information, apparatus, product or process disclosed, or represents that its use would not infringe privately owned rights. Reference herein to any specific commercial product, process, or service by trade name, trademark, manufacturer, or otherwise does not necessarily constitute or imply its endorsement, recommendation, or favoring by the United States Government or any agency thereof. The views and opinions of authors express herein do not necessarily state or reflect those of the United States Government or any agency thereof. 


\begin{abstract}
SRI is developing ceramic-based microsensors for detection of exhaust gases such as NO, $\mathrm{NO}_{2}$, and $\mathrm{CO}$ in advanced combustion and gasification systems. The sensors detect the electrochemical activity of the exhaust gas species on catalytic electrodes and are designed to operate at high temperatures, elevated pressures, and corrosive environments typical of large power generation exhausts. Under this research project we are developing sensors for multiple gas detection in a single package along with data acquisition and control software and hardware. The sensor package can be easily integrated into online monitoring systems for active emission control. This report details the research activities performed from May 2004 to October 2004 including testing of catalytic materials, sensor design and fabrication, and software development.
\end{abstract}




\section{TABLE OF CONTENTS}

DISCLAIMER

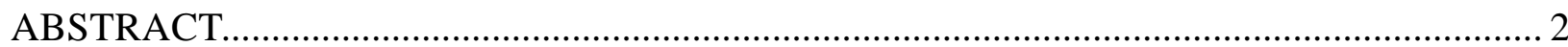

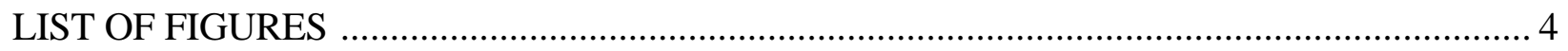

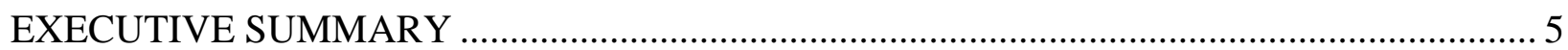

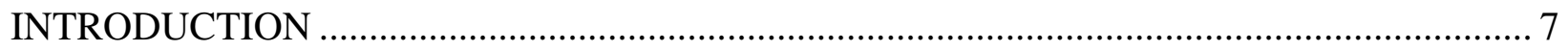

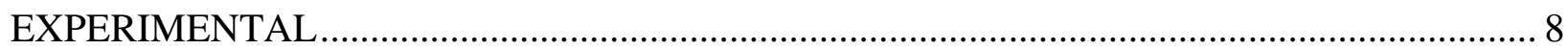

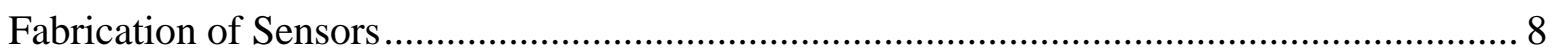

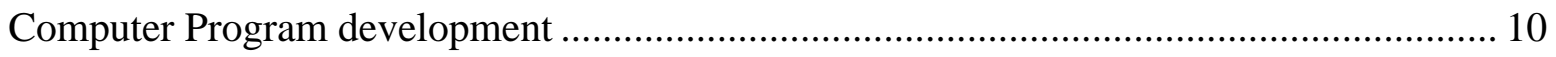

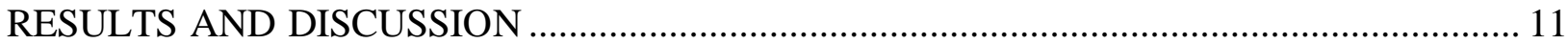

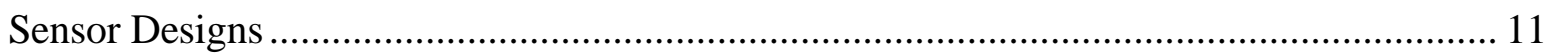

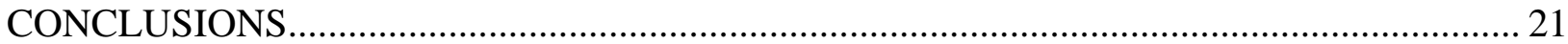

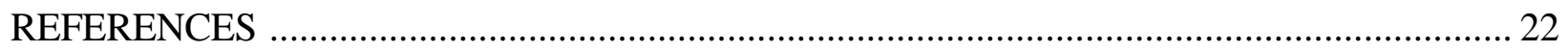




\section{LIST OF FIGURES}

Figure 1. Photographs of a single sensor, Pt counter and reference electrodes (left) and catalytic working electrode (right). The contact wires are held in place with a dab of cement.

Figure 2. Photographs of a multi-electrode design; Pt counter electrodes and the reference electrode in the center (left), and catalytic electrodes(right). Catalytic electrodes: 1Nickel chromate, 2-lanthanum strontium ferrite, 3-platinum, and 4-cadmium manganate. ............................................................................................ 9

Figure 3. Experimental setup for testing sensors. …….................................................... 10

Figure 4. Two sensor designs (A1 and A2). In both designs, the catalytic electrode and auxiliary electrodes are in the emission gas stream. Only the placement of reference electrode is different............................................................................ 12

Figure 5. Square wave voltammogram for $\mathrm{NO}$ at $700^{\circ} \mathrm{C}$ on $\mathrm{NiCr}_{2} \mathrm{O}_{4}$ electrodes. ................... 13

Figure 6. Square wave voltammogram for $\mathrm{NO}_{2}$ at $700^{\circ} \mathrm{C}$ on $\mathrm{NiCr}_{2} \mathrm{O}_{4}$ electrodes................... 13

Figure 7. Sensor design (B) with Pt/air reference electrode. The catalytic electrode and the counter electrode are in the emission gas stream.

Figure 8. Sensor design (C) with Pt/air reference electrode. The catalytic electrode is in the emission gas stream. The counter electrode and the reference electrode are in the air side.

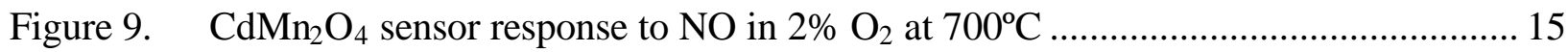

Figure 10. Sensor design (D) with Pt/air reference electrode. The catalytic electrode is underneath a porous YSZ membrane in the emission gas stream. The counter electrode and the reference electrode are in the air side.

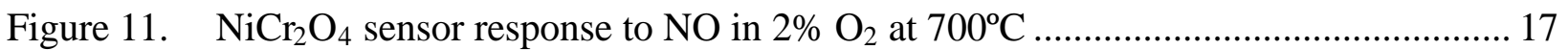

Figure 12. Sensor design (E) with Pt/air reference electrode. The catalytic electrode is underneath a porous-dense YSZ membrane in the emission gas stream. The counter electrode and the reference electrode are in the air side........................................ 17

Figure 13. $\mathrm{CdMn}_{2} \mathrm{O}_{4}$ sensor $\mathrm{E}$ response to $\mathrm{NO}_{2}$ in $5 \% \mathrm{O}_{2}$ at $500^{\circ} \mathrm{C}$....................................... 18

Figure 14. Calibration plot for $\mathrm{CdMn}_{2} \mathrm{O}_{4}$ sensor $\mathrm{E}$ response to $\mathrm{NO}_{2}$ in $5 \% \mathrm{O}_{2}$ at $500^{\circ} \mathrm{C}$........... 18

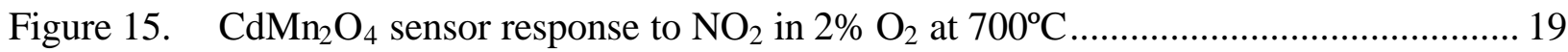

Figure 16. Calibration plot for $\mathrm{CdMn}_{2} \mathrm{O}_{4}$ sensor response to $\mathrm{NO}_{2}$ in $2 \% \mathrm{O}_{2}$ at $700^{\circ} \mathrm{C}$.............. 20 


\section{EXECUTIVE SUMMARY}

To address the critical need for on-line emission monitoring in advanced fossil fuel energy production systems, SRI is developing an array of miniature solid-state electrochemical sensors that are reliable, rugged, and inexpensive. These sensors are based on solid-state ionic conducting materials and catalytic materials and could be used for on-line, real time detection of $\mathrm{O}_{2}, \mathrm{NO}_{\mathrm{x}}, \mathrm{SO}_{\mathrm{x}}, \mathrm{HC}$ and $\mathrm{CO}$ in exhaust gases. The sensors measure potential (potentiometric) and/or current (amperometric and voltammetric) in a solid-state electrochemical cell. The sensor array will consist of a series of electrochemical cells fabricated with yttria-stabilized zirconia (YSZ) solid-state electrolyte and catalytic working electrodes. Each working electrode material is designed to be selective to a specific gas in the gas mixture. Selective detection of gases is further accomplished by application of fast-pulse voltammetric techniques on the specific catalytic electrodes optimized for the gas of interest. The configuration and geometry of the electrode are also critical to obtain the best sensor response. Thus, our research work included selection and synthesis of suitable catalytic materials for detection of $\mathrm{NO}, \mathrm{NO}_{2}$, and $\mathrm{CO}$; fabrication of YSZ ceramic membranes with controlled microstructure; preparation of catalytic electrodes; electrochemical cell design; software development for pulse voltammetry; and testing of sensors in a simulated exhaust environment.

Based on literature and our previous experiments, we selected $\mathrm{CdMn}_{2} \mathrm{O}_{4}$ and $\mathrm{NiCr}_{2} \mathrm{O}_{4}$ as potential candidates for $\mathrm{NO}$ and $\mathrm{NO}_{2}$ detection. These materials were prepared by solid-state synthetic routes, and their phase structures were confirmed by x-ray diffraction. The materials were ball-milled for 12-24 hours to obtain fine particle sizes. For electrode fabrication we used nanoparticles, which we separated from the powder by preparing slurries in terpinol and letting the larger particles settle down.

YSZ membranes for the electrolyte were prepared by tape casting, a procedure similar to one used in commercial fabrication of multilayer capacitors. A slip of YSZ powder in an organic liquid mixture was prepared with added dispersants, binders, plasticizer, and release agents. The slip was then cast into a tape on a glass plate using a doctor blade. Once the tape was dry, required cell geometries were cut with a laser and sintered at $1400^{\circ} \mathrm{C}$ to obtain ceramic membranes. The catalytic electrodes were painted on the membranes using terpinol as the vehicle. The counter and reference electrodes were prepared using commercial platinum ink. The sensor was heated to $750^{\circ} \mathrm{C}$ to sinter the electrode material.

To run the pulse voltammetry waveforms on sensors, we developed software using Microsoft Visual Basic. We interfaced PAR 283 potentiostat (EG\&G) and mass flow controller unit to a computer for data acquisition and experiment control. Also, we have built a sensor test station with multiple mass flow controllers and a programmable furnace.

We designed and fabricated a number of sensors with different electrode configurations. We tested these sensor designs with emission gas species to determine the sensitivity and selectivity in the presence of 1 to $5 \%$ of oxygen. The tests were performed at temperatures from $500^{\circ}$ to $900^{\circ} \mathrm{C}$ and the data are presented in this semi-annual report.

We are conducting this microsensor research program in two phases. Phase I includes the proof of concept and preliminary demonstration of a package with multiple sensors. Phase II 
involves in-depth analysis and testing of sensor arrays for stability, sensitivity, and selectivity; prototype development and testing; and identifying pathways for use of integrated sensor systems in fossil fuel energy conversion systems. The research activities in this report were performed as part of the Phase I effort. 


\section{INTRODUCTION}

The use of sensors can provide the electrical power industry with increased operational efficiency, reduced emissions, and lower operating costs. Advancements in robust sensing and control algorithms can accelerate the time to fullscale commercial implementation of novel power generation technologies such as advanced combustion, gasification, and turbines. While the monitoring of oxygen content is the primary method of optimization of the combustion process, emission control requires monitoring of $\mathrm{NO}_{\mathrm{x}}, \mathrm{SO}_{\mathrm{x}}, \mathrm{CO}$, and hydrocarbons (HC). For closed-loop control, fast-response, reliable sensors are needed near the combustion zone. However, the harsh conditions prevalent in the conversion of fossil fuel to energy create a barrier to making many of the desired measurements. These conditions include high temperatures (up to $1000^{\circ} \mathrm{C}$ ), elevated pressures (up to $500 \mathrm{psi}$ ), corrosive environments, and high particulate loading.

To address the critical need of on-line emission monitoring in advanced fossil fuel energy production systems, SRI proposed to develop an array of miniature solid-state electrochemical sensors that are reliable, rugged, and inexpensive. These sensors are based on solid-state ionic conducting materials and catalytic materials and could be used for on-line, real time detection of $\mathrm{O}_{2}, \mathrm{NO}_{\mathrm{x}}, \mathrm{SO}_{\mathrm{x}}, \mathrm{HC}$ and $\mathrm{CO}$ in exhaust gases.

In general, most high-temperature gas sensors operate on the principle that change in gas composition is related to a corresponding change in property such as potential, current, capacitance, or resistance. The proposed sensors in this research project measure potential (potentiometric) and/or current (amperometric and voltammetric) in a solid-state electrochemical cell. The sensor array will consist of a series of electrochemical cells fabricated with yttriastabilized zirconia (YSZ) solid-state electrolyte and catalytic working electrodes. Each working electrode material is designed to be selective to a specific gas in the gas mixture. It is also of great significance that the sensor materials are stable in the operational environment for a period up to one year. Gases are selectively detected by application of fast-pulse voltammetric techniques on the specific catalytic electrodes optimized for the gas of interest. The configuration and geometry of the electrode are critical to obtain the best sensor response. Thus, the research work reported here included fabrication of ceramic electrochemical cell components with controlled microstructure, which would increase the selectivity, sensitivity, and response time of the sensor.

We are conducting this research program in two phases. Phase I, which is the focus of this report, includes the proof of concept and preliminary demonstration of multiple sensors. Phase II involves in-depth analysis and testing of sensor arrays for stability, sensitivity, and selectivity; prototype development and testing; and identifying pathways for use of integrated sensor systems in fossil fuel energy conversion systems. Successful completion of this proposed research program will provide an economical method to monitor emission gas in fossil energy applications. The ability to manufacture and install reliable sensor systems with high stability, high reliability, and long service life at a low cost will significantly improve clean energy generation technology and will help to reach the goals of the DOE NETL Instrumentation Sensor and Control Systems Program. 


\section{EXPERIMENTAL}

For initial evaluation, we selected three materials, $\mathrm{CdMn}_{2} \mathrm{O} 4, \mathrm{NiCr}_{2} \mathrm{O}_{4}$, and $\mathrm{LaCuO}_{4}$ based on literature and our previous experience. We also evaluated lanthanum strontium ferrite for its activity towards emission gases. During this reporting period, we fabricated number of sensors on zirconia membranes (50-150 $\mu \mathrm{m}$ thick and $1.5 \mathrm{~cm}$ diameter) with these materials as the catalytic electrodes. Sensor fabrication involved preparation of YSZ membranes, deposition of auxiliary electrodes, deposition of catalytic electrodes, addition of electrical contacts, and mounting of the cell in the test housing. The sensors were then tested under variety of emission conditions.

\section{Fabrication of Sensors}

The sensors were fabricated on YSZ membranes, which served as the electrolyte. The base zirconia membranes (electrolyte) were prepared by tape casting. The electrolyte was painted one side with platinum ink and the other side with cadmium manganate or nickel chromate and fired at $850^{\circ} \mathrm{C}$ for 1 hour. Some sensors were made with all platinum electrodes. In another set of experiments electrode sintering temperature was reduced to $750^{\circ} \mathrm{C}$ and the sintering time was increased to 3 hours to improve bonding of the electrode to the electrolyte. The electrical contacts to the electrodes were made with fine Pt wires $(0.1 \mathrm{~mm})$. The contact wires were held in place by small amount of Aremco cement. Figures 1 and 2 show single and multielectrode sensor designs, respectively, that we used in most experiments. In both cases, the counter electrode was painted about the same size as the catalytic electrode and it was placed exactly opposite side of the catalytic electrode. The reference electrode was offset from the counter electrode by at least 3 times the thickness of the electrolyte. Numerous variations of this basic design were fabricated to optimize the selectivity and sensitivity of the sensors. The sensors were mounted to an alumina tube using Aremco cement. The sensor element end of the tube was placed in a high temperature furnace. We performed the initial testing between $500^{\circ}$ and $800^{\circ} \mathrm{C}$ in the experimental setup shown in Figure 3. The details of the test setup were given in the first semi-annual report. 

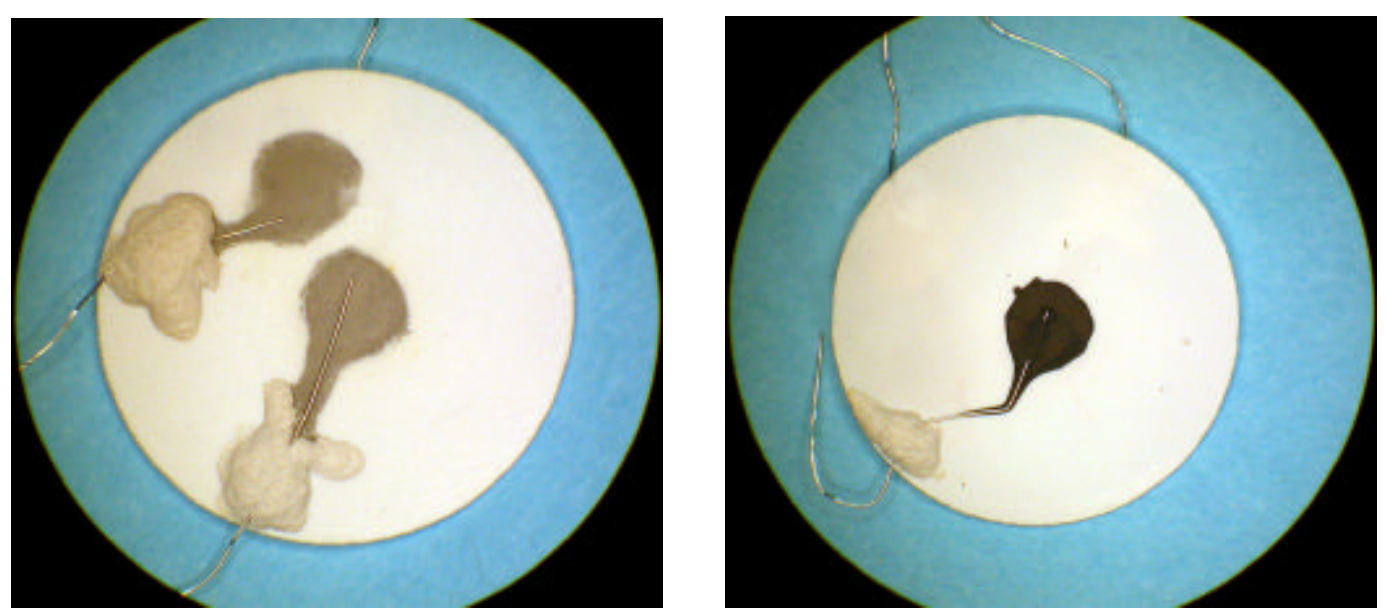

Figure 1. Photographs of a single sensor, Pt counter and reference electrodes (left) and catalytic working electrode (right). The contact wires are held in place with a dab of cement.
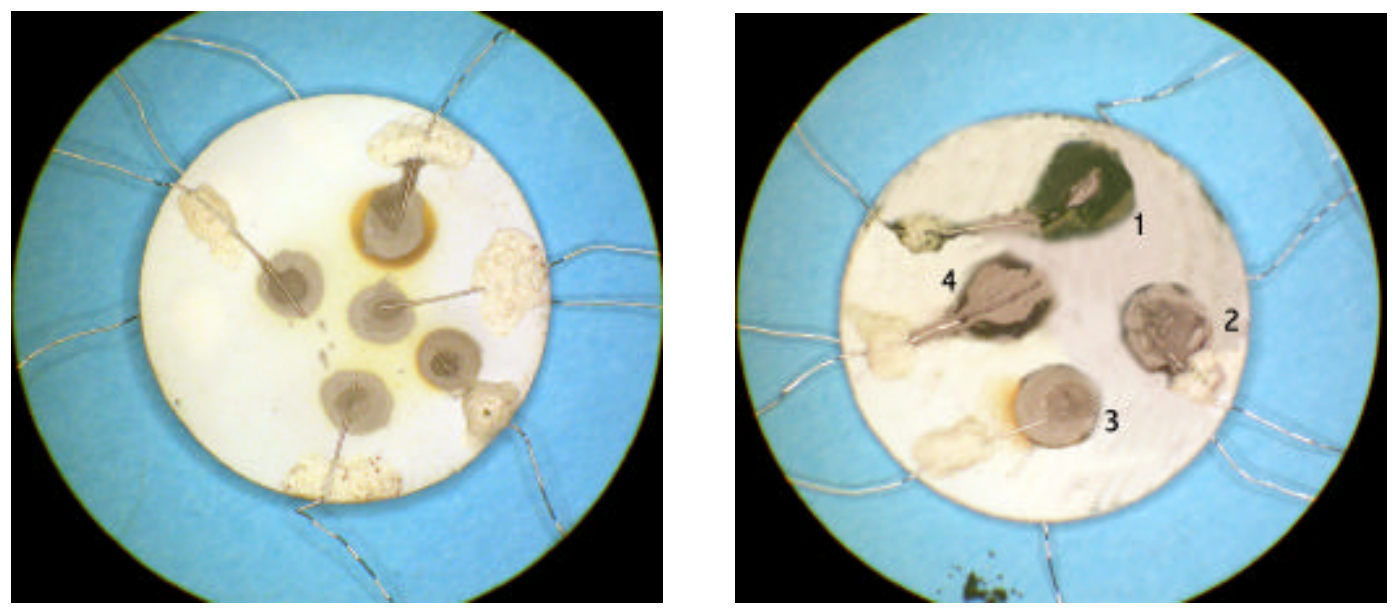

Figure 2. Photographs of a multi-electrode design; Pt counter electrodes and the reference electrode in the center (left), and catalytic electrodes (right). Catalytic electrodes: 1-Nickel chromate, 2-lanthanum strontium ferrite, 3platinum, and 4-cadmium manganate. 


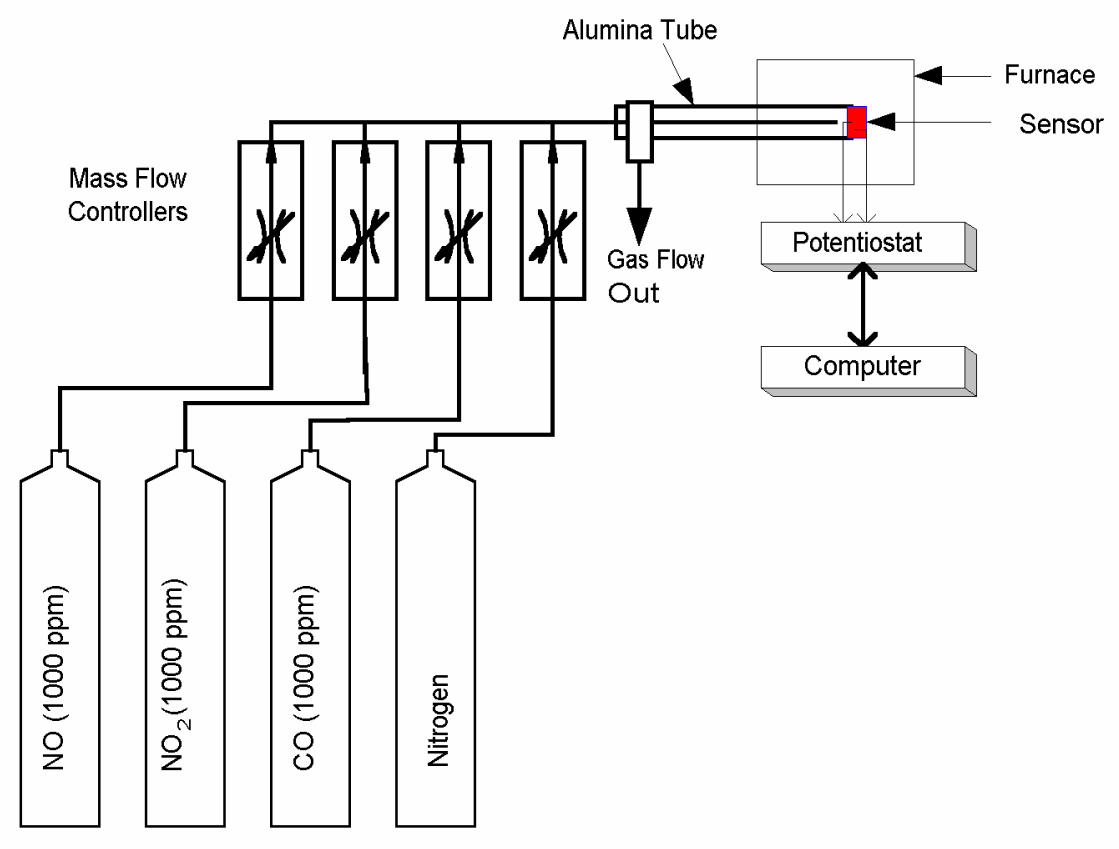

Figure 3. Experimental setup for testing sensors.

\section{Computer Program development}

Since the commercial software package we bought with the potentiostat did not provide sufficient flexibility for the type of planned experiments, we wrote the data acquisition and experimental software in our laboratory. Initial codes for square wave voltammetry were developed with Microsoft Visual Basic during the first six months of the project. In this reporting period, we continued to refine the software for experiment control and data acquisition. 


\section{RESULTS AND DISCUSSION}

In potentiometric measurements, $\mathrm{CdMm}_{2} \mathrm{O}_{4}$ has shown selectivity to $\mathrm{NO}$ at $600^{\circ} \mathrm{C}(1)$ and $\mathrm{NiCr}_{2} \mathrm{O}_{4}$ has shown to be selective for $\mathrm{NO}_{2}$ at $650^{\circ} \mathrm{C}(2)$. Both of these compounds are insensitive to $\mathrm{CO}, \mathrm{CO}_{2}, \mathrm{HC}$ and $\mathrm{O}_{2}$ according to published literature (1-3). In this reporting period, we tested a number of sensor designs with $\mathrm{CdMn}_{2} \mathrm{O}_{4}$ and $\mathrm{NiCr}_{2} \mathrm{O}_{4}$ catalytic electrodes. We also tested lanthanum strontium ferrite (LSF) for its catalytic activity towards emission gases.

\section{Sensor Designs}

The sensor designs that we tested so far are shown in Figures 4 through 8. In the sensor design shown in Figure 4, all electrodes are in the emission gas stream. The advantage of this design is that sensor does not need to be sealed to the housing, and only the electrical connections are fed through the walls. In addition, the ceramic sensor elements are not attached to the housing, and thus the difference in thermal expansion of materials does not result in any stress on the elements minimizing the sensor failure due to thermal shock.

The difference in designs A1 and A2 is the placement of the reference electrode. The reference electrode is placed on the surface of the inactive area of the electrolyte, some distance away from the edge of the active electrodes. In A1, the reference electrode is placed on the counter electrode side, and in A2, it is place on the working electrode side. It was found that both designs yield similar results provided that the reference electrode is placed at a distance more than three times the electrolyte thickness away from the edge of the active electrodes. The reference electrode measures the electrolyte potential along the equipotential surface somewhere between the two active electrodes. After more than three times the electrolyte thickness away from the edge of the active electrodes, the potential measured is essentially the potential at the center of the electrolyte regardless of the placement side of the reference electrode. However, the disadvantage of this design is that the reference electrode potential can vary depending on the emission gas composition and, thus peak positions can move leading to difficulty in species identification. 


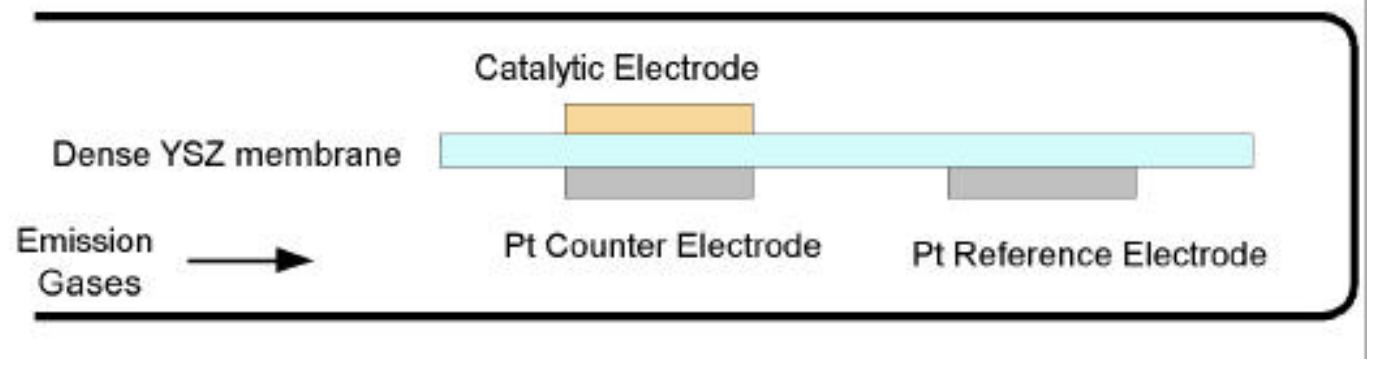

(1)

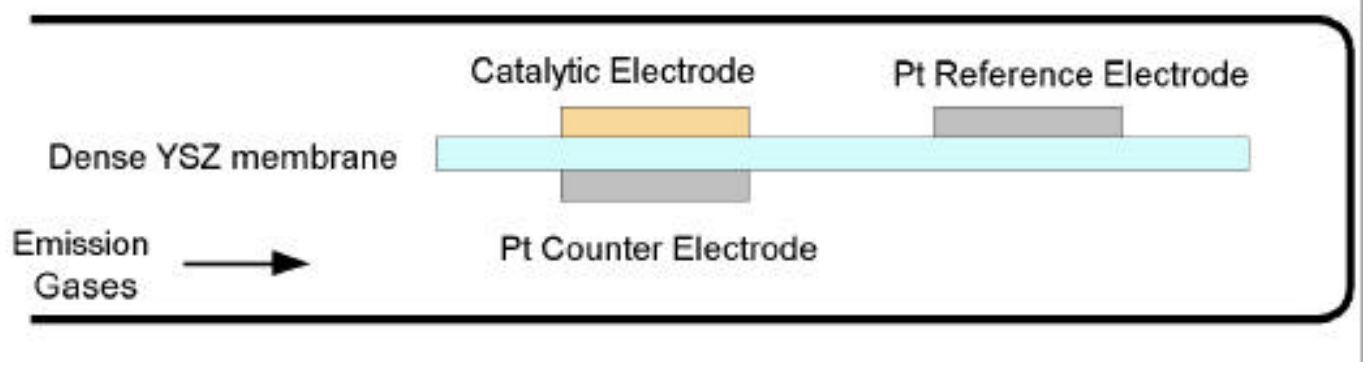

(2)

Figure 4. Two sensor designs (A1 and A2). In both designs, the catalytic electrode and auxiliary electrodes are in the emission gas stream. Only the placement of reference electrode is different.

Figures 5 and 6 show the response of the sensor A1 with a $\mathrm{NiCr}_{2} \mathrm{O}_{4}$ catalytic electrode to $1000 \mathrm{ppm} \mathrm{NO}$ and $1000 \mathrm{ppm} \mathrm{NO}_{2}$ in $1 \% \mathrm{O}_{2}$ at $700^{\circ} \mathrm{C}$, respectively. Although the peaks were broader than expected and the sensitivity was low, the results clearly demonstrated the use of pulse voltammetry for the detection of emission gases. The peaks broadening and low sensitivity can be ascribed to high diffusion coefficient and low activation energy of electroactive species in the gas phase at $700^{\circ} \mathrm{C}$. Because of the high diffusion rate, it is difficult to establish mass transfer control during the potential scan. The sensitivity and the resolution can be increased by better electrode design and better electrode fabrication. However, uncertainty of the reference electrode potential in this design made it difficult to establish peak positions, and thus we decided to continue further work with sensor designs that have a Pt/air reference electrode. 


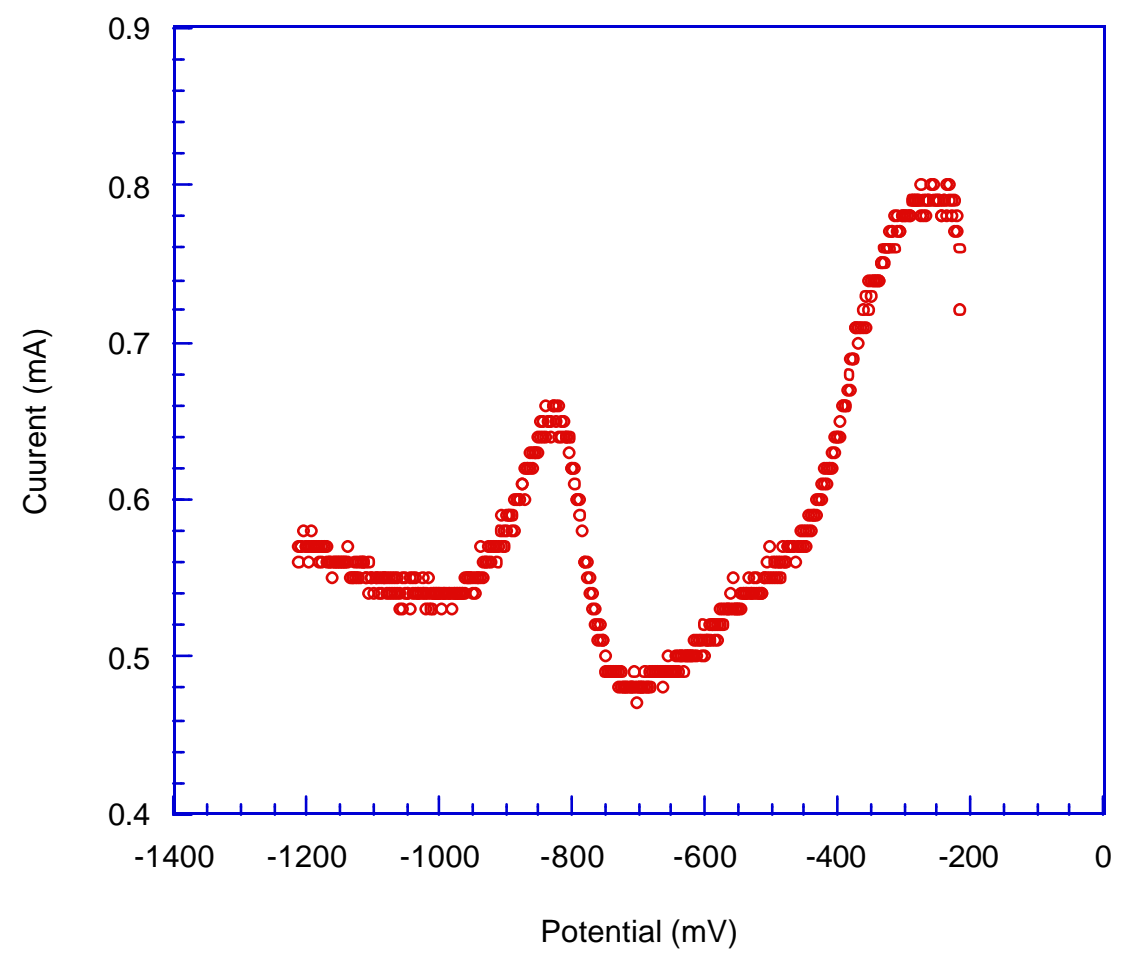

Figure 5. Square wave voltammogram for $\mathrm{NO}$ at $700^{\circ} \mathrm{C}$ on $\mathrm{NiCr}_{2} \mathrm{O}_{4}$ electrodes.

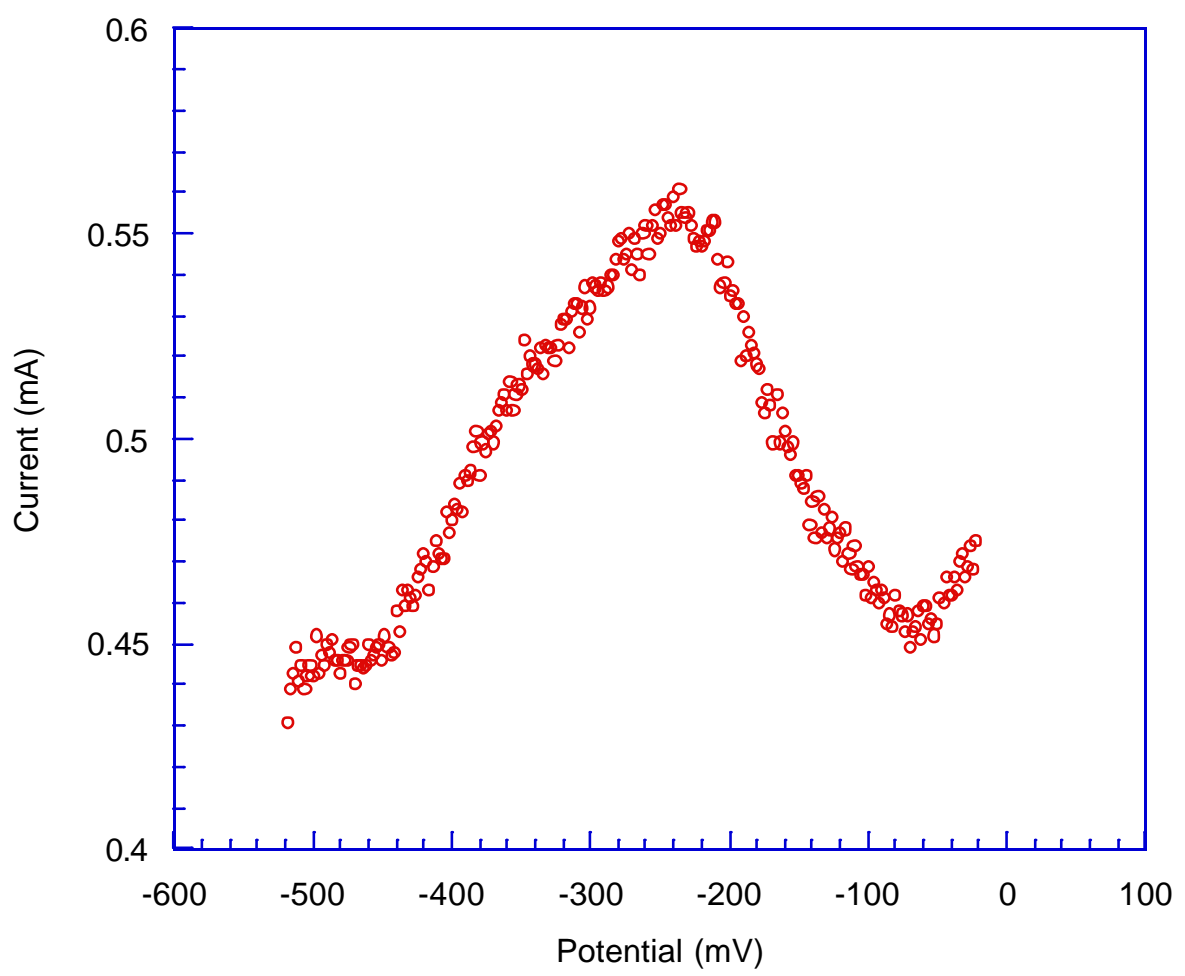

Figure 6. Square wave voltammogram for $\mathrm{NO}_{2}$ at $700^{\circ} \mathrm{C}$ on $\mathrm{NiCr}_{2} \mathrm{O}_{4}$ electrodes. 
The sensor design shown in Figure 7 has both working and counter electrodes in the emission gas side and the reference electrode is in the airside. The electrode chambers were formed by sealing the cell to an alumina tube housing. Since the reference electrode is in equilibrium with the ambient air, its potential is determined by the Nernst potential according to the concentration of oxygen in the atmosphere. The placement of the electrode is also reasonably good as it measures an equipotential surface between the two active surfaces. However, the cell current flows laterally through the membrane, and thus the cell resistance is significantly higher than the previous design. This poses problem in pulse voltammetric techniques where it is needed to force high double layer charging and faradaic currents through the cell during pulsing. At lower temperatures where the response of species to the catalytic electrodes are at best, $\left(\sim 600^{\circ} \mathrm{C}\right)$, the electronics became unstable due to high impedance of the cell. Therefore, we determined that this design was not suitable for pulse voltammetric techniques where a significant amount of current is passed through the cell during the measurements. However, in potentiometric measurements, this sensor design would work well as no appreciable current is passed through the cell.

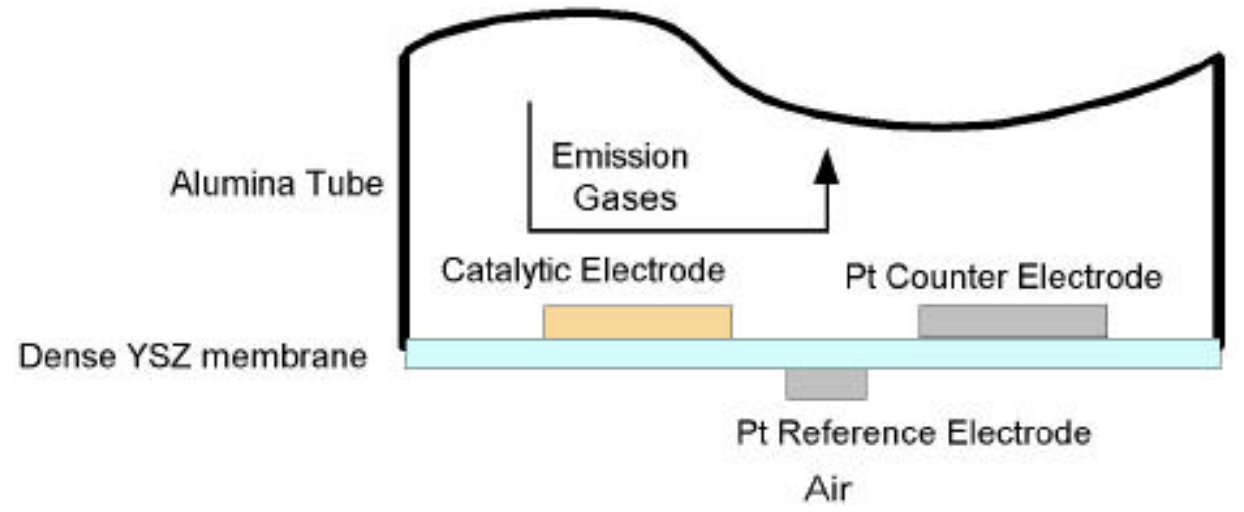

Figure 7. Sensor design (B) with Pt/air reference electrode. The catalytic electrode and the counter electrode are in the emission gas stream.

The sensor design $\mathrm{C}$ shown in Figure 8 is the design mostly studied in this research project. In this design, only the catalytic electrode is in the emission gas stream. Both reference and counter electrodes are placed outside in ambient air, and thus the reference electrode potential is fixed by the oxygen in air similar to the previous design. Similar to design B, the electrolyte is sealed to the cell housing (alumina tube) in the cell design $\mathrm{C}$, separating anodic and cathodic chambers.

The cell resistance of the design $\mathrm{C}$ is relatively small as the electrolyte is thin $(50-200 \mu \mathrm{m})$, and thus we could perform voltammetric potential scans in this cell without making it electronically unstable. For low temperature measurements $\left(500^{\circ} \mathrm{C}\right)$ the cell was further stabilized by capacitively coupling the reference and counter electrodes. We used the smallest capacitor that provided the stable cell circuit without compromising the response speed. The typical capacitors were in the 0.001 to $0.1 \mu \mathrm{F}$ range. 


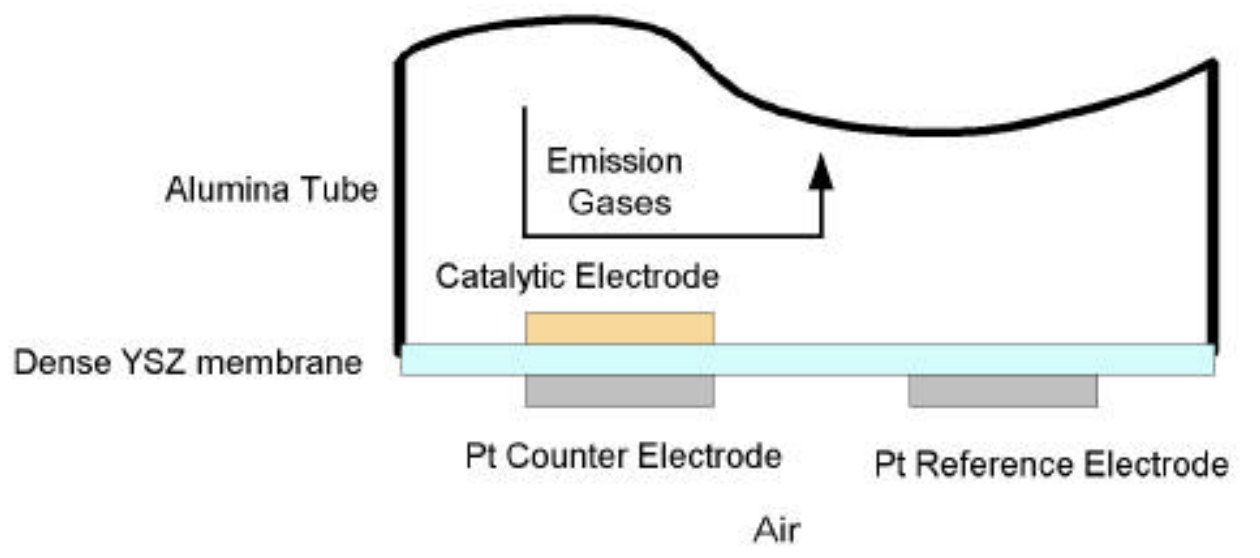

Figure 8. Sensor design (C) with Pt/air reference electrode. The catalytic electrode is in the emission gas stream. The counter electrode and the reference electrode are in the airside.

Figure 9 show the response of sensor design $\mathrm{C}$ with a $\mathrm{CdMn}_{2} \mathrm{O}_{4}$ electrode to $\mathrm{NO}$ in $2 \% \mathrm{O}_{2}$ at $700^{\circ} \mathrm{C}$. The differential current peak was broad and the background current was high indicating fast mass transfer at the electrode. It was difficult to obtain accurate calibration curves for low concentrations with this cell design. To improve the cell response in pulse voltammetric measurements, it is critical to establish mass transfer control of the electrochemical reaction. For this purpose, we used porous YSZ membranes.

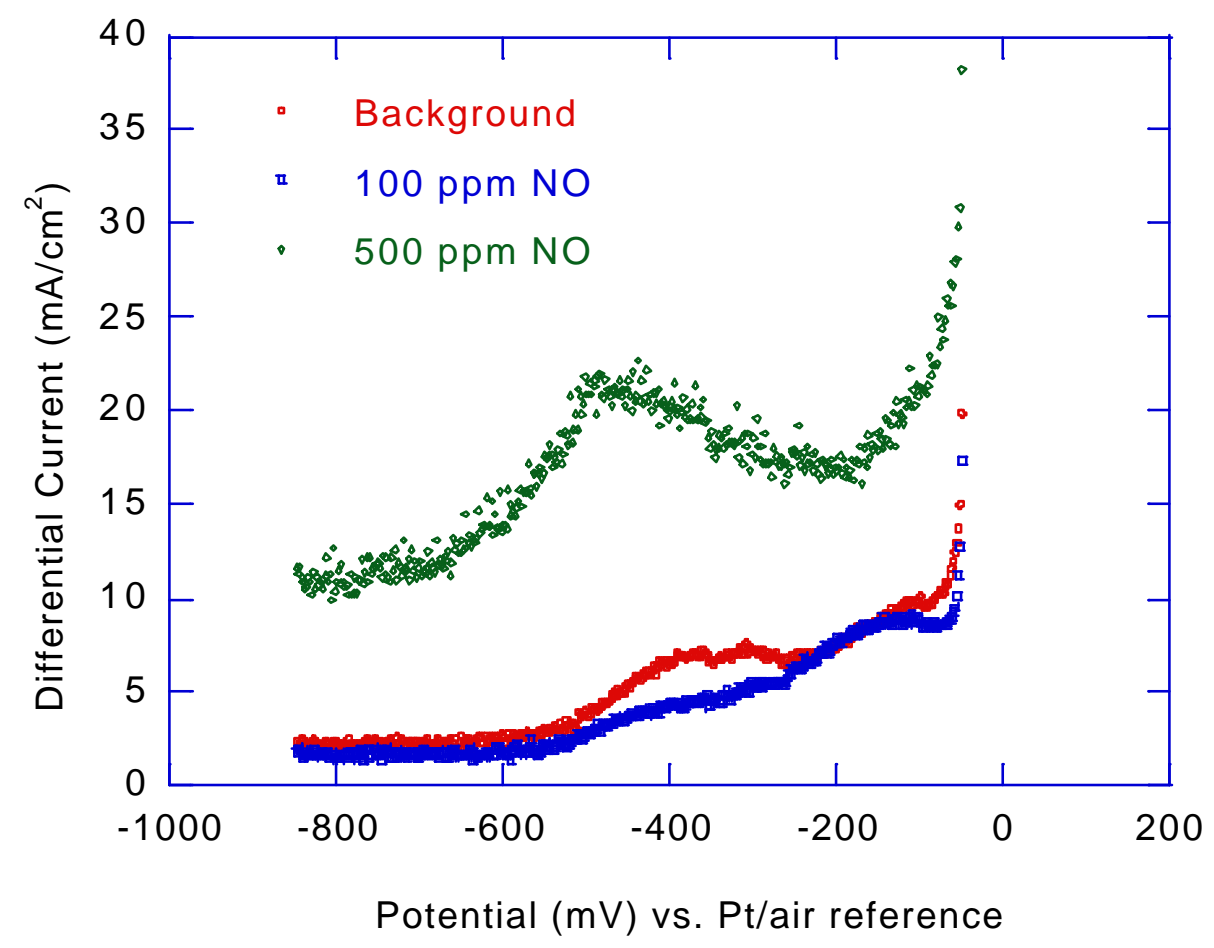

Figure 9. $\mathrm{CdMn}_{2} \mathrm{O}_{4}$ sensor response to $\mathrm{NO}$ in $2 \% \mathrm{O}_{2}$ at $700^{\circ} \mathrm{C}$ 
The sensor design D shown in Figure 10 is a modification of $\mathrm{C}$ where gas flow to the catalytic electrode is restricted with a porous YSZ membrane. The sensor D is fabricated by attaching the porous YSZ to the sensor $\mathrm{C}$ with Aremco cement. By restricting the diffusion of gases to the electrode, we managed to improve the performance of the sensor significantly. Figure 11 shows the response of $\mathrm{NiCr}_{2} \mathrm{O}_{4}$ electrode to $\mathrm{NO}_{2}$ in $2 \% \mathrm{O}_{2}$ at $700^{\circ} \mathrm{C}$. The sensor response is clearly improved with design $\mathrm{C}$, and thus the detection limit is significantly improved. To further optimize the sensor response, we decided to use a highly restricted flow design

The sensor design $\mathrm{E}$ shown in Figure 12 is another modification of $\mathrm{C}$ where gas flow to the catalytic electrode is further restricted with a porous/dense YSZ membrane. The gases are allowed to reach the catalytic electrode via the small pinhole and the porous layer. Sensor E is fabricated by attaching the porous/dense YSZ to the sensor $\mathrm{C}$ with Aremco cement, and then piercing a fine hole in the top dense layer with a micro-drill. By restricting the diffusion of gases to the electrode, we significantly improved the sensitivity and the selectivity of the sensor.

Figure 13 shows the response of sensor $\mathrm{E}$ with a $\mathrm{CdMn}_{2} \mathrm{O}_{4}$ electrode to $\mathrm{NO}_{2}$ in $5 \% \mathrm{O}_{2}$ at $500^{\circ} \mathrm{C}$. The high background current is due to oxygen in the gas stream. Clearly, the electrode responded well to the changes in the concentration of $\mathrm{NO}_{2}$. Figure 14 shows the calibration curve obtained from these plots indicating excellent linearity in the tested NO concentration range.

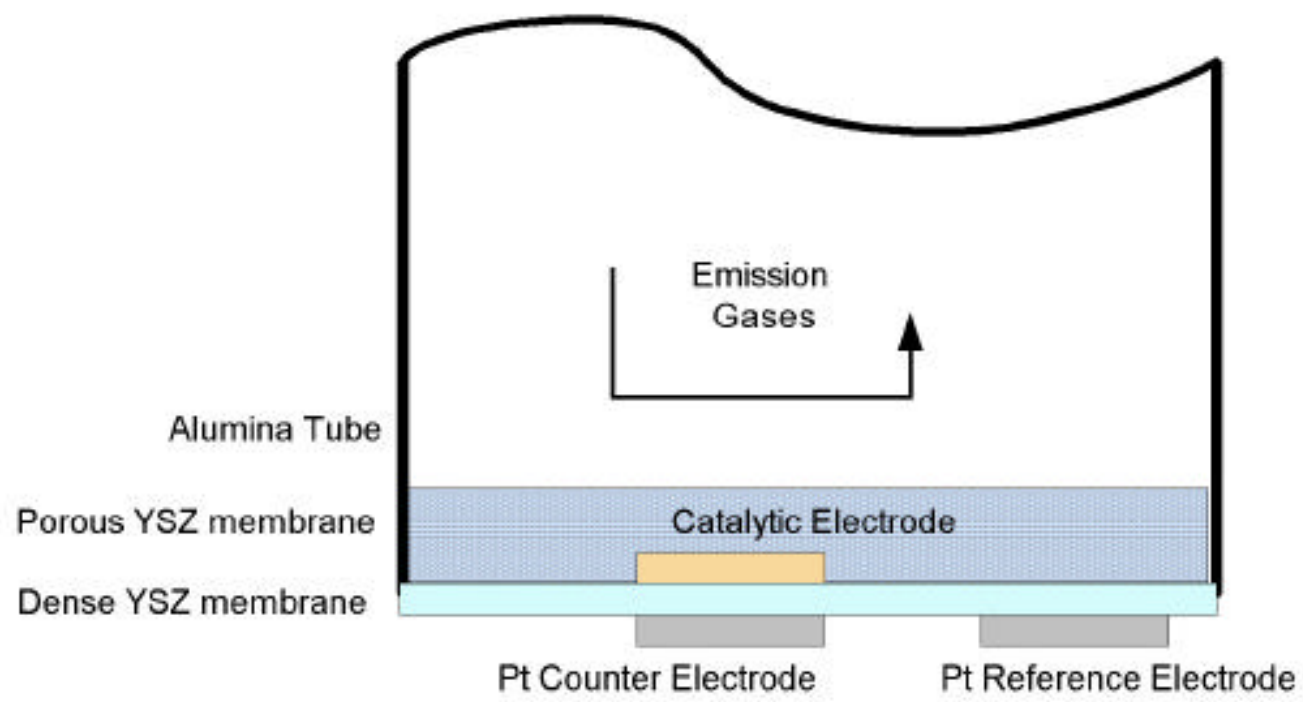

Air

Figure 10. Sensor design (D) with Pt/air reference electrode. The catalytic electrode is underneath a porous YSZ membrane in the emission gas stream. The counter electrode and the reference electrode are in the airside. 


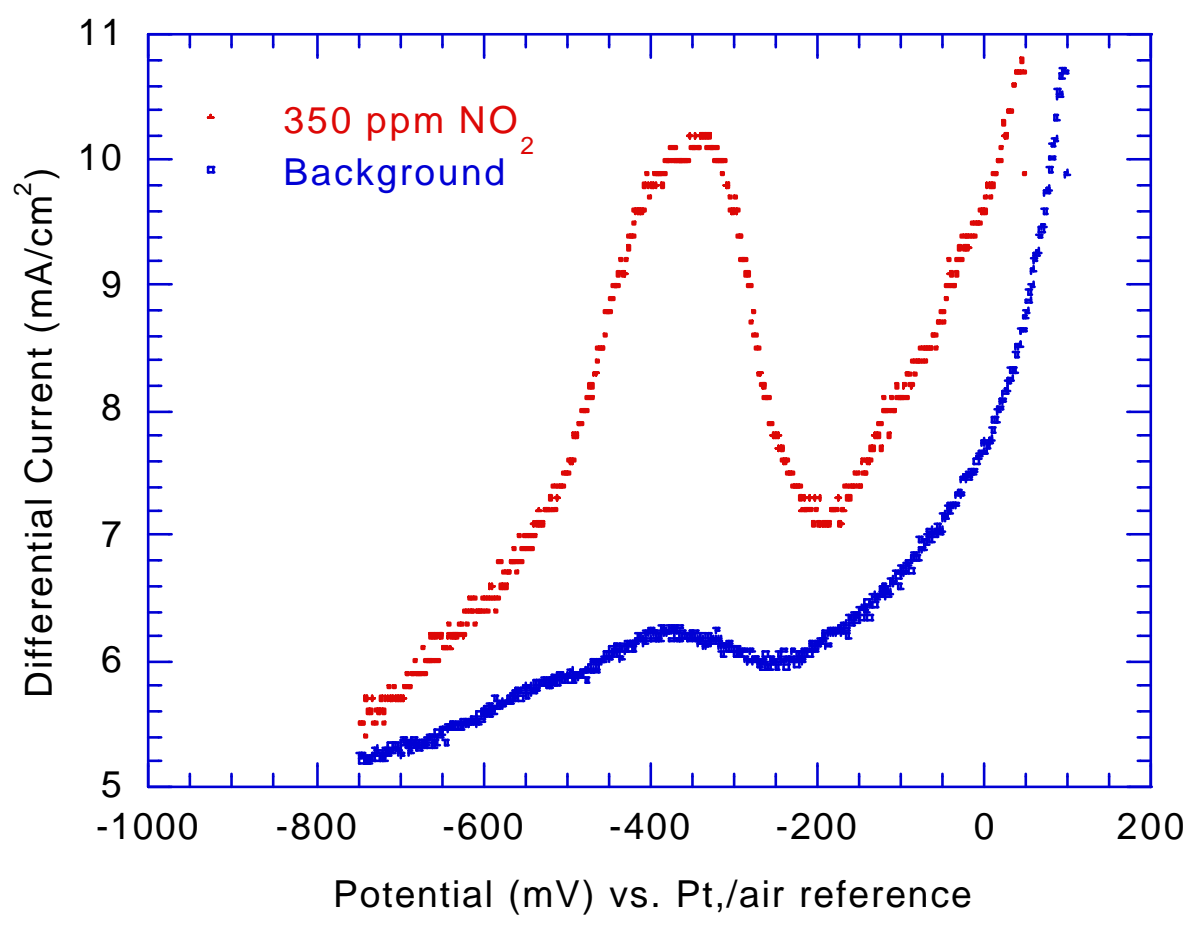

Figure 11. $\mathrm{NiCr}_{2} \mathrm{O}_{4}$ sensor response to $\mathrm{NO}$ in $2 \% \mathrm{O}_{2}$ at $700^{\circ} \mathrm{C}$

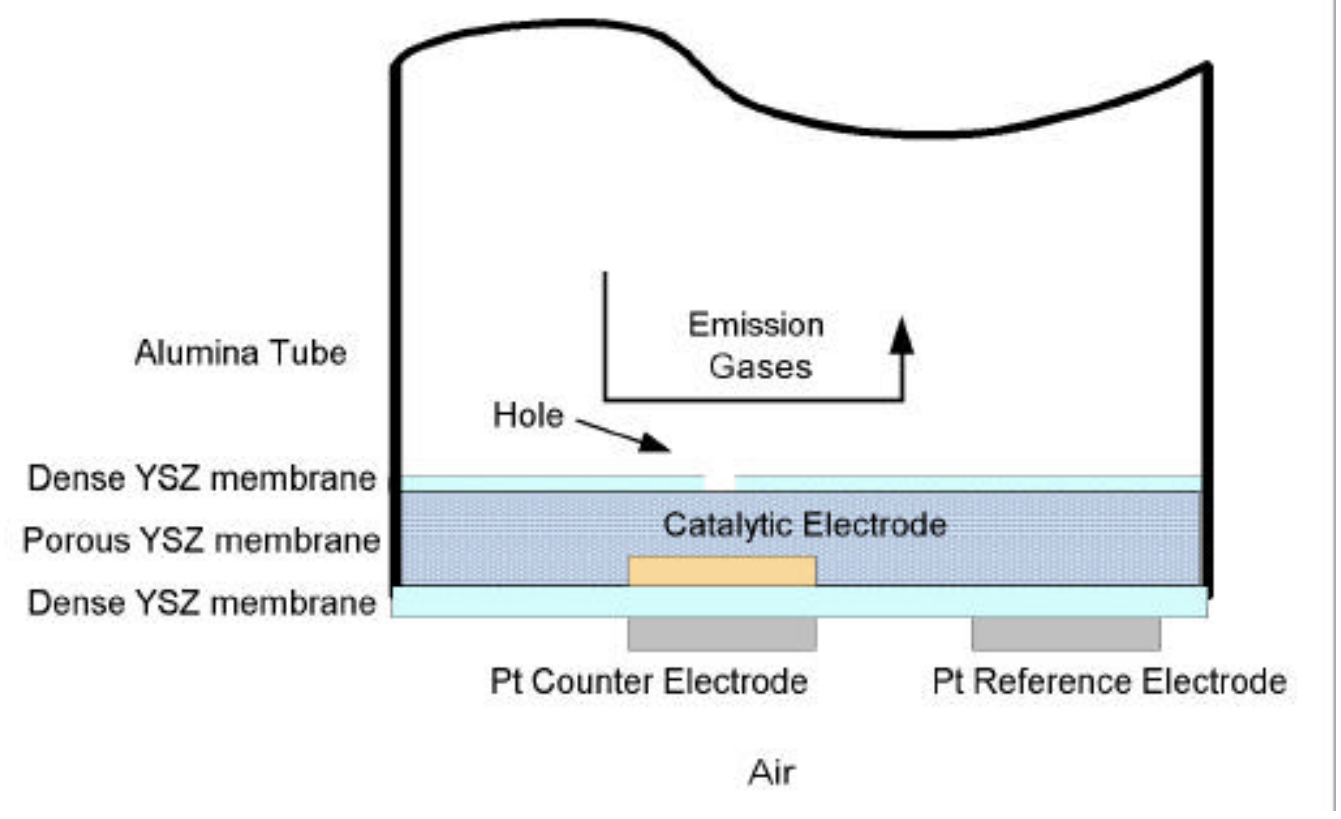

Figure 12. Sensor design (E) with Pt/air reference electrode. The catalytic electrode is underneath a porous-dense YSZ membrane in the emission gas stream. The counter electrode and the reference electrode are in the airside. 


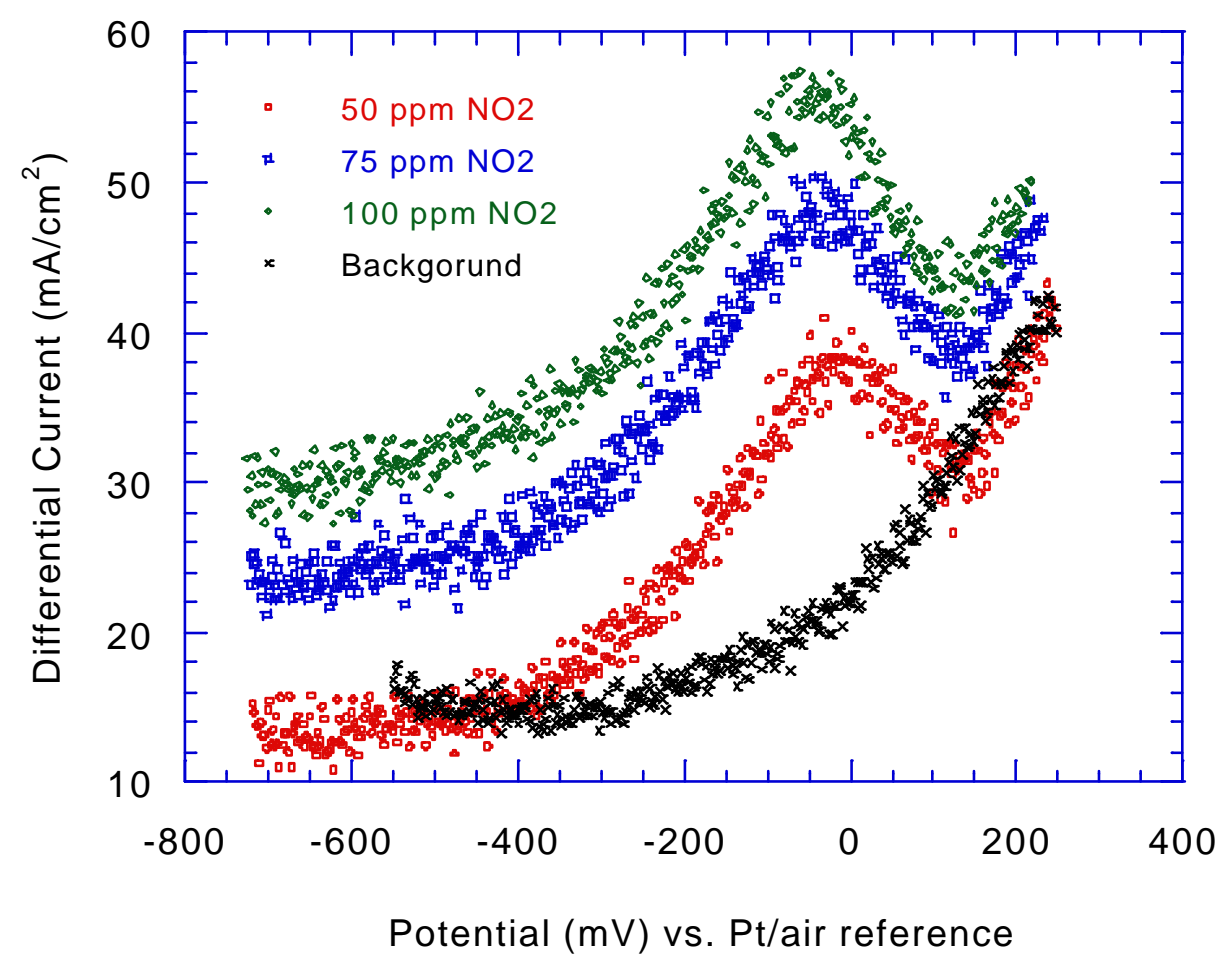

Figure 13. $\mathrm{CdMn}_{2} \mathrm{O}_{4}$ sensor $\mathrm{E}$ response to $\mathrm{NO}_{2}$ in $5 \% \mathrm{O}_{2}$ at $500^{\circ} \mathrm{C}$

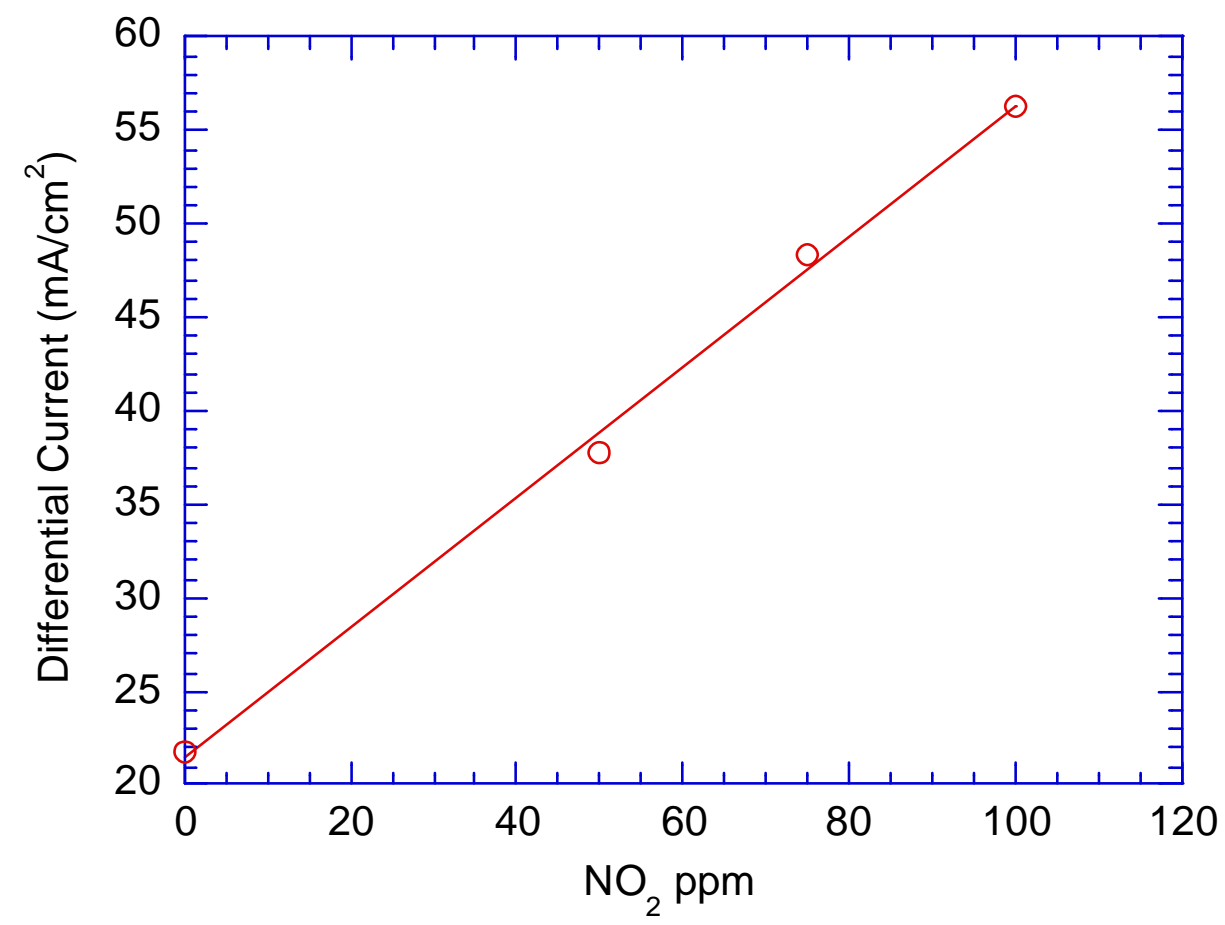

Figure 14. Calibration plot for $\mathrm{CdMn}_{2} \mathrm{O}_{4}$ sensor $\mathrm{E}$ response to $\mathrm{NO}_{2}$ in $5 \% \mathrm{O}_{2}$ at $500^{\circ} \mathrm{C}$ 
Figure 15 shows the response of sens or $\mathrm{E}$ with a $\mathrm{CdMm}_{2} \mathrm{O}_{4}$ electrode to $\mathrm{NO}_{2}$ in $2 \% \mathrm{O}_{2}$ at $700^{\circ} \mathrm{C}$. The peak position is slightly shifted as the concentration of oxygen in the gas stream and the temperature is different from the previous experiment. Nevertheless, the electrode responded well to the changes in the concentration of $\mathrm{NO}_{2}$. The noise level in the response signal was lower at high temperature as cell resistance is low. Figure 16 shows the calibration curve obtained from these plots indicating excellent linearity in the tested NO concentration range.

We have just started testing LSF electrode with the sensor design E in NO and Co gas streams. We will present the results of these tests in the Phase I final report.

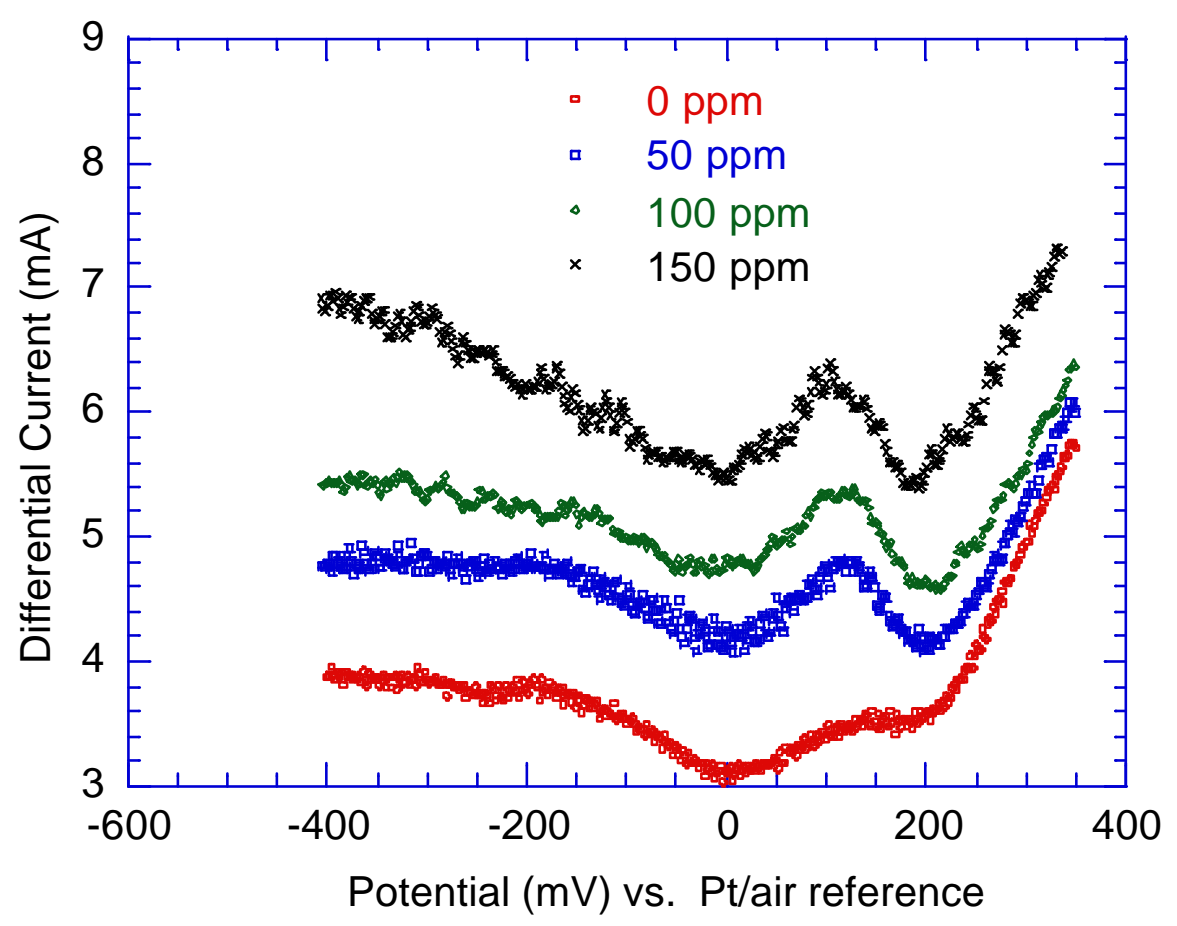

Figure 15. $\mathrm{CdMn}_{2} \mathrm{O}_{4}$ sensor response to $\mathrm{NO}_{2}$ in $2 \% \mathrm{O}_{2}$ at $700^{\circ} \mathrm{C}$ 


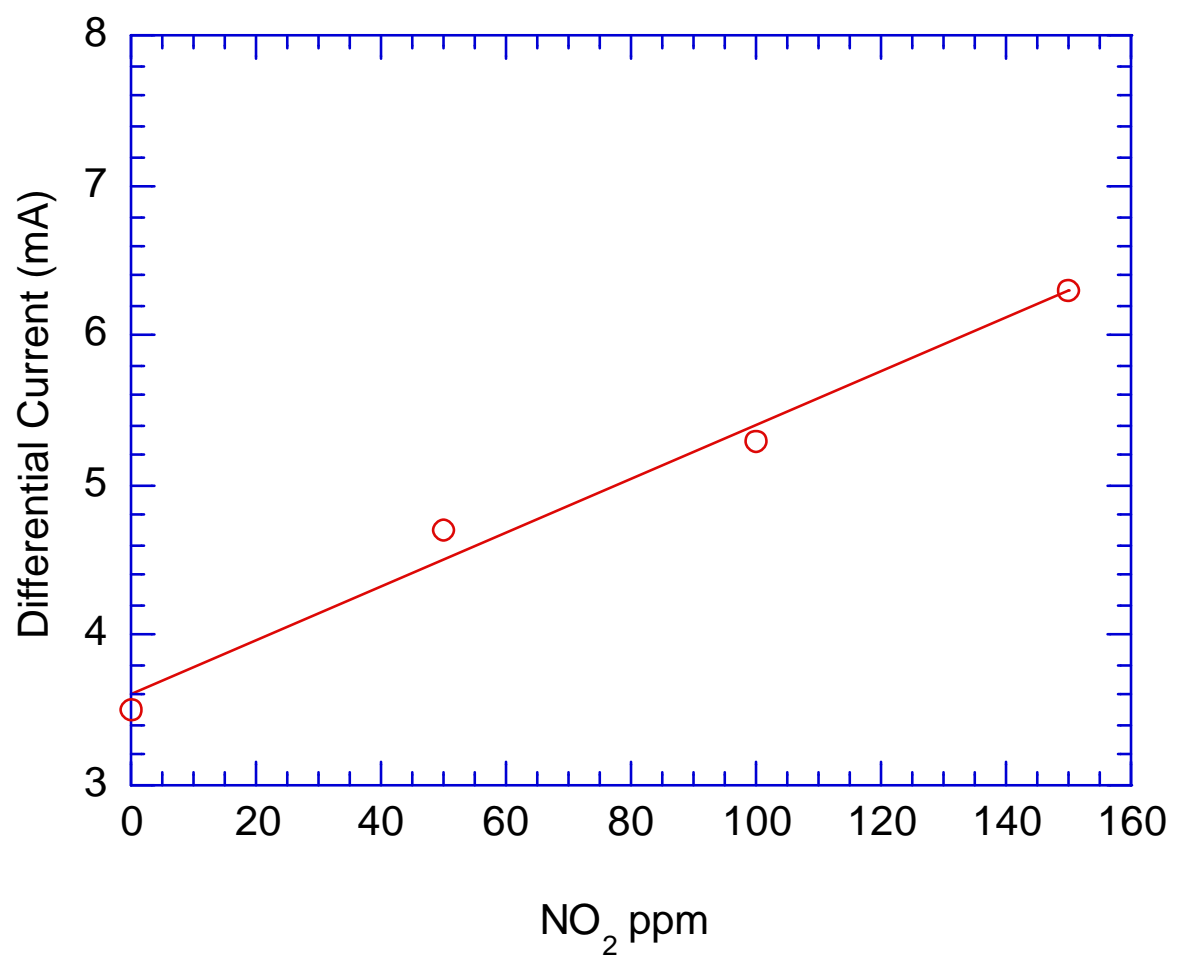

Figure 16. Calibration plot for $\mathrm{CdMm}_{2} \mathrm{O}_{4}$ sensor response to $\mathrm{NO}_{2}$ in $2 \% \mathrm{O}_{2}$ at $700^{\circ} \mathrm{C}$ 


\section{CONCLUSIONS}

We have tested three catalytic materials for their selectivity and sensitivity for emission gases to be used as catalytic electrodes in pulse voltammetric analysis. A number of sensor designs were fabricated using $\mathrm{CdMn} 2 \mathrm{O} 4, \mathrm{NiCr}_{2} \mathrm{O}_{4}$ and $\mathrm{LSF}$ as catalytic electrodes and they were tested for their performance at temperatures $500^{\circ}$ to $800^{\circ} \mathrm{C}$. We varied the geometry, methods of fabrication of electrodes, and the potential scan parameters to optimize the performance of sensors.

Both $\mathrm{NO}_{2}$ and $\mathrm{NO}$ can be detected on either $\mathrm{CdMn}_{2} \mathrm{O} 4$ or $\mathrm{NiCr}_{2} \mathrm{O}_{4}$ electrodes in a diffusionrestricted cell. Since the appearing potentials of the peaks are different, the species can be easily identified in the voltammogram. The cell and electrode design was critical to obtain the sensitivity and selectivity as the diffusion of gases to the catalytic electrode must be restricted to obtain mass transfer controlled in the electrochemical reactions. A simple cell design with a catalytic electrode did not provide adequate sensitivity or selectivity for the detection of emission gases. This is primarily due to high mass transfer rate in the gas phase. The charge transfer rate was not sufficient to establish a mass transfer controlled reaction, and thus the cell current would not reach a plateau as in the case in typical aqueous solutions.

We have completed software development and instrument interface for the sensor testing experiments. In the next month, we will continue to optimize the sensors to improve the selectivity and sensitivity. Currently, we are testing LSF catalytic electrodes with NO and CO gases. We will present our findings in the Phase I final report. 


\section{REFERENCES}

1. N. Miura, G. Lu and N. Yamazoe, Sensors Actuators, B 52 (1998) 169.

2. G. Lu, N. Miura and N. Yamazoe, J. Appl. Electrochem., 28 (1998) 1009.

3. S. Somov, G. Reinhardt, U. Guth and W. Gopel, Sensors Actuators, B 35-36 (1996) 409. 
